\title{
Performance of lemongrass (Cymbopogon citrates) oil as growth promoter in broiler
}

\author{
MR Tiwari ${ }^{1}$, PK Jha*2, ${ }^{3}$, B Sah ${ }^{1}$, G Kunwar ${ }^{4}$ and AK Jha ${ }^{4}$
}

${ }^{1}$ Animal Nutrition Division, Khumaltar, Lalitpur; ${ }^{2}$ Animal Breeding Division, Khumaltar, Lalitpur, Nepal; ${ }^{3}$ Department of Surgery and Obstetrics, Bangladesh Agricultural University, Bangladesh; ${ }^{3}$ Institute of Agriculture and Animal Science, Tribhuwan University, Kirtipur, Kathmandu; ${ }^{4}$ Regional Agricultural Research Station, Parwanipur, Bara, Nepal

\begin{abstract}
An attempt was taken to study the growth performance of lemongrass oil (Cymbopogon citraturs) as a growth promoter on the broiler production. A total of 180day-old broiler chicks were procured from private hatchery (Shivam Hatchery Birgung, Parsa, Nepal) and were allocated following Completely Randomized Design (CRD) into four treatment groups (each treatment with 3 replications and each replication with 15 birds); $T_{1}=$ control, $T_{2}=$ containing lemongrass oil $200 \mathrm{ml} / 100 \mathrm{~kg}$ feed, $T_{3}=$ containing lemongrass oil $400 \mathrm{ml} / 100 \mathrm{~kg}$ feed and, $\mathrm{T}_{4}=$ containing lemongrass oil $600 \mathrm{ml} / 100 \mathrm{~kg}$ feed. The study was carried out for 36 days at Avian Research Unit, Regional Agriculture Research Station, Parwanipur, Bara, Nepal. Concentrate mixture and lemongrass oil were procured from Shakti Feed Industry, Birgung; Herbs Processing Plant of Ministry of Forest and Soil Conservation, Jadibuti, Kathmandu, respectively. Experimental birds were provided ad libitum amount of starter feed from 0 to 21 days and finisher feed from 22 to 36 days. Feed intake was recorded daily and body weight gain was measured in 7 days interval. The study revealed that the cumulative feed intake per bird was found higher in $\mathrm{T}_{3}(3443.17 \mathrm{~g})$ followed by $\mathrm{T}_{4}(3377.33 \mathrm{~g})$ and $\mathrm{T}_{2}(3354.04 \mathrm{~g})$, respectively, and were statistically non-significant among the diet groups. The FCR was highest in $T_{3}(1: 1.44 \mathrm{~kg})$ and lowest in $T_{4}(1: 1.51$ $\mathrm{kg})$, and differed insignificantly among the diet groups. Similarly, the total weight gain of the experimental bird was found to be higher in $T_{3}(2385.13 \mathrm{~g})$ followed by $T_{1}(2279.46 \mathrm{~g})$ and $\mathrm{T}_{2}(2271.86 \mathrm{~g})$, respectively. The average daily gain of experimental birds noted higher in $T_{3}(66.25 \mathrm{~g})$ followed by $T_{1}$ and $T_{2}(63.31 \mathrm{~g})$ and $(63.1 \mathrm{~g})$, respectively. The experiment suggested that inclusion of lemongrass oil could be considered as an alternative to antibiotic growth promoter in broiler diet to enhance the production performance.
\end{abstract}

Key words: broiler chicken, lemongrass oil, growth performance, Nepal

Bangladesh Animal Husbandry Association. All rights reserved.

Bang. J. Anim. Sci. 2018. 47 (2): 85-91

\section{Introduction}

Livestock is an integral component of the mixed agricultural farming system in Nepal, contributing $29 \%$ of agriculture GDP (Gross Domestic Product), and about $11.5 \%$ of total national GDP (MoAD, 2072/73). The demand of increasing population shifting towards poultry farming for income generation and fulfill needs. In Nepal, the poultry farming is popular and at the apex comparing with other livestock commodities. The estimated total population of poultry in Nepal is about 68.63 million and producing 55041 metric ton meat per annum (Krishi Diary, 2017). Poultry meat as a diet is an important source of highquality protein, minerals and vitamins for human health.. The demand for poultry meat is high compared to sheep and goat meats.
To meet the increasing consumer's demand, Nepalese researcher is trying their efforts to increase safe, healthy and economic poultry production. On the other hand, they want to make sure this does not decrease the quality of the end product or ignore animal welfare. In particular, with the ban on the use of antibiotics to increase growth, studies on plant-based alternatives have emphasized. Performance enhancers until recently called growth promoters are used to improve animal growth rate and/or feed conversion ratio. One of the feed additives used to enhance the growth and found increasing performance in poultry is lemongrass (Cymbopogon citraturs; Peter and Babu, 2012). Lemongrass is herb and proved to have health and medicinal benefits. This grass contains flavonoids, phenolic compounds, terpenoids(Lewis, 1986) and essential oils (such

*Corresponding author: drpankaj.np@gmail.com 
as citral a, citral $\beta$, nerolgeraniol, citronellal, terpinolene,geranyl methylheptenone) which may be responsible for its different biological activities such as antibacterial, antidiarrheal, antifungal, antioxidants, and as a growth promoter (Shah et al., 2011). Several studies have been reported the use of lemongrass or its secondary metabolites for performance-enhancing purposes in poultry, especially in broilers (Mmereole, 2010; Mukhtar et al, 2012; Thayalini et al., 2011), pigs (Tartrakoon et al., 2002) and rabbits (Omer et al., 2010). Mmereole (2010) and Mukhtar et al. (2012) reported that lemongrass could be used asan alternative to antibiotics. The lemongrass metabolites as an oil (LGO) is considered as a viable alternative to antibiotics for the broiler and have been studied as an alternative for microbial and growth promoting abilities in the poultry, and that resulted minimized feed expense in the production chain.. Several studies have been carried out on incorporating LGO in broiler diet as a supplement would stimulate the growth performance of broilers (Bampidis et al., 2005; Cross et al., 2007). Mukhtar et al. (2012) reported that broilers fed diets supplemented with different levels of LGO significantly consumed more feed and improved body weight gain compared to the control group. In Nepal, commercial poultry farmers are using antibiotics in the poultry diet as a growth promoter which is a hazard for human health. In this context, the inclusion of LGO in broiler diet is the most promising alternative of antibiotics. Therefore, this study was carried out with an aim to evaluate the effect of different levels of LGOoil in broiler diet for growth performance of commercial broilers.

\section{Materials and Methods}

The study was carried out during the period of December 2017 to January 2018 at Avian Research Unit, Regional Agricultural Research Station (RARS), Parwanipur, Bara, Nepal. The birds were procured from Shivam Hatchery, Birgung, Parsa, Nepal. The compound feed was procured from Shakti Feed Industry, Birgung, Parsa, Nepal. Lemongrass oil was procured from Herbs processing plant of ministry of forest and soil conservation, Jadibuti, Kathmandu. The proximate analysis of the feed samples both treated and untreated was estimated at Animal Nutrition Division, Khumaltar, Lalitpur, Nepal.

\section{Proximate analysis}

Respective samples were analyzed for dry matter $(D M)$, organic matter (OM), total ash (TA), crude protein (CP) and crude fiber (CF) contents. The dry matter was determined by oven drying at $100^{\circ} \mathrm{C}$ for 24 hours. Crude protein was analyzed using the Kjeldahl method. Ash content was determined by ash at $550^{\circ} \mathrm{C}$ in a muffle furnace for 16 hours ((AOAC, 1980). The crude fiber of the samples was determined using the Van Soest method (Goering and Van Soest, 1970).

\section{Birds management}

The birds were kept in an opened house and raised on floor pens $(0.90 \mathrm{~m} 2 /$ bird $)$ for 36 days. In the first week, all the birds had received vaccination against Ranikhet disease ('F1' strain; RDF) one drop/bird as recommended by world poultry science. Concentrate feed mixture was given on group basis and provided to the experimental birds once a day in the morning in adlib amount for both periods (starter 0- 21 days and finisher 22-36 days). Clean drinking water was provided inadequate amount and water were made available at all times. The light was provided for 24 hours, natural light during the day and artificial light during night during the entire experimental period.

\section{Experimental design}

A total of 180 day-old broiler chicks were allocated into four treatment group; $\mathrm{T}_{1}=$ control, $\mathrm{T}_{2}=$ containing lemongrass oil $200 \mathrm{ml} / 100 \mathrm{~kg}$ concentrate mixture feed, $T_{3}=$ containing lemongrass oil $400 \mathrm{ml} / 100 \mathrm{~kg}$ concentrate mixture feed, and $\mathrm{T}_{4}=$ containing lemongrass oil $600 \mathrm{ml} / 100 \mathrm{~kg}$ concentrate mixture feed. A Completely Randomized Design (CRD) was applied with three replication having 15 birds in each replication.

\section{Observation and data recording}

The trial period consisted for 36 days. The quantity of concentrate mixture given daily to the birds in group weighed daily and refusal was weighed in the next morning. The body weight gain measurement was done in a group basis (replication wise) in seven days interval in the morning before feed supply.

\section{Data analysis}

Data of feed intake and body weight gain was analyzed by one-way analysis of variance (ANOVA) by using computer statistical package SPSS version 16 . 


\section{Results}

Table 1: Chemical composition of the feeds (on DM basis \%)

\begin{tabular}{|c|c|c|c|c|c|c|}
\hline \multirow[t]{2}{*}{ Treatment } & DM & OM & TA & CP & CF & Gross energy, Kcal \\
\hline & \multicolumn{5}{|c|}{ Starter feed (1-21 days) } & \\
\hline 1 & 89.31 & 94.68 & 5.32 & 18.07 & 5.53 & \\
\hline 2 & 93.5 & 94.58 & 5.42 & 18.59 & 6.47 & \\
\hline 3 & 89.19 & 97.31 & 2.69 & 18.12 & 7.16 & \\
\hline \multirow[t]{2}{*}{4} & 89.01 & 94.39 & 5.61 & 18.35 & 5.91 & \\
\hline & & & \multicolumn{3}{|c|}{ Finisher feed ( $22-36$ days) } & \\
\hline 1 & 93.48 & 92.99 & 7.01 & 14.67 & 7.18 & \\
\hline 2 & 92.95 & 94.35 & 5.65 & 14.14 & 5.44 & \\
\hline 3 & 94.09 & 94.04 & 5.96 & 14.76 & 5.29 & \\
\hline 4 & 93.6 & 93.63 & 6.37 & 14.41 & 7.43 & \\
\hline Lemongrass oil & NA & NA & NA & 7.79 & NA & 8701.26 \\
\hline
\end{tabular}

N. B. In poultry diet, lysine, methionine and tryptophan are essential element but due to unavailability of apparatus for above said element analysis it could not be performed.

\section{Feed intake}

Table 2 showed the average feed intake of experimental birds. It was observed that in the $7^{\text {th }}$ days of the experiment, highest feed intake per bird was recorded in $T_{1}(40.8 \mathrm{~g})$ followed by $\mathrm{T}_{3}$ $(39.02 \mathrm{~g})$ and $\mathrm{T}_{4}(38.22 \mathrm{~g})$, respectively, and varied significantly $(\mathrm{P}<0.05)$ among the diet groups. In $14^{\text {th }}$ days of the experiment, feed intake per bird of $T_{1}(77.82 \mathrm{~g})$ and $T_{4}(77.37 \mathrm{~g})$, and $T_{2}(76.93 \mathrm{~g})$ and $T_{3}(77.3 \mathrm{~g})$ was almost similar and, were observed non-significant among diet groups. In $21^{\text {st }}$ days of the experiment, highest feed intake per bird was noted int 4 (128.48g) followed by $T_{1}(125.24 \mathrm{~g})$ and $T_{2}$ $(124.53 \mathrm{~g})$, respectively, and were observed nonsignificant among the diet groups. Similarly, in $28^{\text {th }}$ days of the experiment, highest feed intake per bird was observed in $T_{3}(168.39 \mathrm{~g})$ followed by $T_{2}(166.57 \mathrm{~g})$ and $T_{1}(165.46 \mathrm{~g})$, respectively, and were observed non-significant among diet groups. Likewise, in $36^{\text {th }}$ days of the experiment, again highest feed intake per bird was found to be in $T_{3}(199.82 \mathrm{~g})$ followed by $T_{2}(187.33 \mathrm{~g})$ and $\mathrm{T}_{4}$ (184. 84g), respectively, however were observed non-significant among the diet groups. The cumulative feed intake per bird was found higher in $T_{3}(3443.17 \mathrm{~g})$ followed by $T_{4}(3377.33 \mathrm{~g})$ and $\mathrm{T}_{2}(3354.04 \mathrm{~g})$, respectively, and were observed non-significant among the diet groups. The FCR was highest in $T_{3}(1: 1.44 \mathrm{~kg})$ and lowest in $\mathrm{T}_{4}(1: 1.51 \mathrm{~kg})$ which were also non-significant among diet groups.

Table 2: Feed intake of experimental birds ( $g$; Mean \pm SD)

\begin{tabular}{lrrrrrrrr}
\hline $\begin{array}{c}\text { Treatm } \\
\text { ent }\end{array}$ & 0 day & 7 days & 14 days & 21 days & 28 days & 36 days & $\begin{array}{c}\text { Cumulati } \\
\text { ve feed } \\
\text { intake }\end{array}$ & $\begin{array}{c}F C R \\
\text { 1 }\end{array}$ \\
\hline 1 & $5.44 \pm 1.35$ & $40.08 \pm 1.08$ & $77.82 \pm 1.57$ & $125.24 \pm 3.37$ & $165.46 \pm 2.70$ & $176.93 \pm 1.02$ & 3330.95 & 1.46 \\
2 & $4.30 \pm 0.33$ & $36.08 \pm 0.65$ & $76.93 \pm 2.20$ & $124.53 \pm 4.10$ & $166.57 \pm 3.24$ & $187.33 \pm 1.09$ & 3354.04 & 1.47 \\
3 & $4.70 \pm 0.60$ & $39.02 \pm 0.90$ & $76.30 \pm 1.44$ & $123.11 \pm 6.22$ & $168.39 \pm 1.48$ & $199.82 \pm 1.32$ & 3443.17 & 1.44 \\
4 & $5.19 \pm 0.70$ & $38.22 \pm 1.98$ & $77.37 \pm 1.42$ & $128.48 \pm 2.43$ & $161.90 \pm 7.06$ & $184.84 \pm 1.93$ & 3377.33 & 1.51 \\
Mean & $4.91 \pm 0.84$ & $38.35 \pm 1.87$ & $77.10 \pm 1.55$ & $125.34 \pm 4.18$ & $165.58 \pm 4.34$ & $187.23 \pm 1.46$ & 3376.37 & 1.47 \\
P-Value & $\mathrm{P}>0.05$ & $\mathrm{P}<0.05$ & $\mathrm{P}>0.05$ & $\mathrm{P}>0.05$ & $\mathrm{P}>0.05$ & $\mathrm{P}>0.05$ & $\mathrm{P}>0.05$ & $\mathrm{P}>0.05$ \\
\hline
\end{tabular}




\section{Body weight gain}

The average growth performance of experimental birds is given in Table 4. It was observed that highest body weight of bird in 7th day of the experiment was recorded in $\mathrm{T}_{3}(182.22 \mathrm{~g})$ followed by $T_{1}(177.77 \mathrm{~g})$ and $T_{4}(175.55 \mathrm{~g})$, respectively. In $14^{\text {th }}$ day of the experiment, again highest body weight was monitored in $T_{3}$ $(486.66 \mathrm{~g})$ followed by $\mathrm{T}_{4}(482.21 \mathrm{~g})$ and $\mathrm{T}_{2}$ $(479.99 \mathrm{~g})$, respectively. In $21^{\text {st }}$ day of the experiment, higher body weight was found in $T_{1}$ $(1033.00 \mathrm{~g})$ followed by $T_{3}(997.77 \mathrm{~g})$ and $T_{4}$ $(986.66 \mathrm{~g})$, respectively. Similarly, in $28^{\text {th }}$ day of the experiment, bird of $\mathrm{T}_{4}$ weighed higher (1688g) than that of $T_{3}(1606.66 \mathrm{~g})$ and $T_{1}$
$(1677.77 \mathrm{~g})$, respectively. Likewise, by the end of the experiment at $36^{\text {th }}$ days, higher weight was found in the $T_{3}(2431 \mathrm{~g})$ followed by $T_{1}(2324 \mathrm{~g})$ and $T_{2}(2316 \mathrm{~g})$, respectively. The inclusion of LOG did not affect significantly on body weight gain during experiment period from initial to end of the experiment ( 36 days). The trend of average body weight gained by the experimental birds is shown in Figure 1. The total weight gain of the experimental bird was found to be higher in $T_{3}$ (2385.13g) followed by $T_{1}(2279.46 \mathrm{~g})$ and $T_{2}$ $(2271.86 \mathrm{~g})$, respectively. The average daily gain of experimental birds noted higher in $T_{3}(66.25 \mathrm{~g})$ followed by $T_{1} \quad(63.31 \mathrm{~g})$ and $T_{2} \quad(63.1 \mathrm{~g})$, respectively.

Table 3: Weight gain of experimental birds, $(g$; Mean \pm SD)

\begin{tabular}{|c|c|c|c|c|c|c|c|c|}
\hline Treatment & $\begin{array}{l}\text { Initial } \\
\text { weight }\end{array}$ & 7 days & 14 days & 21 days & 28 days & 36 days & $\begin{array}{l}\text { Total } \\
\text { weight } \\
\text { gain, g }\end{array}$ & ADG \\
\hline 1 & $\begin{array}{l}44.97 \pm \\
1.03\end{array}$ & $\begin{array}{l}177.77 \pm \\
10.18\end{array}$ & $\begin{array}{l}471.1 \pm \\
23.41\end{array}$ & $\begin{array}{l}1033.0 \pm \\
35.27\end{array}$ & $\begin{array}{l}1677.77 \pm \\
21.42\end{array}$ & $\begin{array}{l}2324.0 \pm \\
1.01\end{array}$ & $\begin{array}{l}2279.46 \pm \\
101.36\end{array}$ & $\begin{array}{l}63.31 \pm \\
2.81\end{array}$ \\
\hline 2 & $\begin{array}{l}43.64 \pm \\
0.75\end{array}$ & $\begin{array}{l}171.10 \pm \\
3.85\end{array}$ & $\begin{array}{l}479.99 \pm \\
17.63\end{array}$ & $\begin{array}{l}984.44 \pm \\
36.71\end{array}$ & $\begin{array}{l}1577.77 \pm \\
86.75\end{array}$ & $\begin{array}{l}2316.0 \pm \\
0.35\end{array}$ & $\begin{array}{l}2271.86 \pm \\
82.61\end{array}$ & $\begin{array}{l}63.10 \pm \\
2.29\end{array}$ \\
\hline 3 & $\begin{array}{l}45.99 \pm \\
1.96\end{array}$ & $\begin{array}{l}182.22 \pm \\
3.84\end{array}$ & $\begin{array}{l}486.66 \pm \\
24.03\end{array}$ & $\begin{array}{l}997.77 \pm \\
63.36\end{array}$ & $\begin{array}{l}1606.66 \pm \\
141.10\end{array}$ & $\begin{array}{l}2431.0 \pm \\
1.24\end{array}$ & $\begin{array}{l}2385.13 \pm \\
126.01\end{array}$ & $\begin{array}{l}66.25 \pm \\
3.50\end{array}$ \\
\hline 4 & $\begin{array}{l}44.22 \pm \\
1.23\end{array}$ & $\begin{array}{l}175.55 \pm \\
3.85\end{array}$ & $\begin{array}{l}482.21 \pm \\
26.94\end{array}$ & $\begin{array}{l}986.66 \pm \\
80.82\end{array}$ & $\begin{array}{l}1688.88 \pm \\
16.77\end{array}$ & $\begin{array}{l}2273.0 \pm \\
6.67\end{array}$ & $\begin{array}{l}2229.10 \pm \\
7.10\end{array}$ & $\begin{array}{l}61.85 \pm \\
0.24\end{array}$ \\
\hline Mean & $\begin{array}{l}44.70 \pm \\
1.45\end{array}$ & $\begin{array}{l}176.66 \pm \\
6.66\end{array}$ & $\begin{array}{l}479.99 \pm \\
20.69\end{array}$ & $\begin{array}{l}1001.0 \pm \\
52.98\end{array}$ & $\begin{array}{l}1637.77 \pm \\
86.70\end{array}$ & $\begin{array}{l}2336.0 \pm \\
98.20\end{array}$ & $\begin{array}{l}2291.39 \pm \\
97.99\end{array}$ & $\begin{array}{l}62.62 \pm \\
2.73\end{array}$ \\
\hline P- Value & $P>0.05$ & $P>0.05$ & $P>0.05$ & $P>0.05$ & $P>0.05$ & $P>0.05$ & $P>0.05$ & $P>0.05$ \\
\hline
\end{tabular}

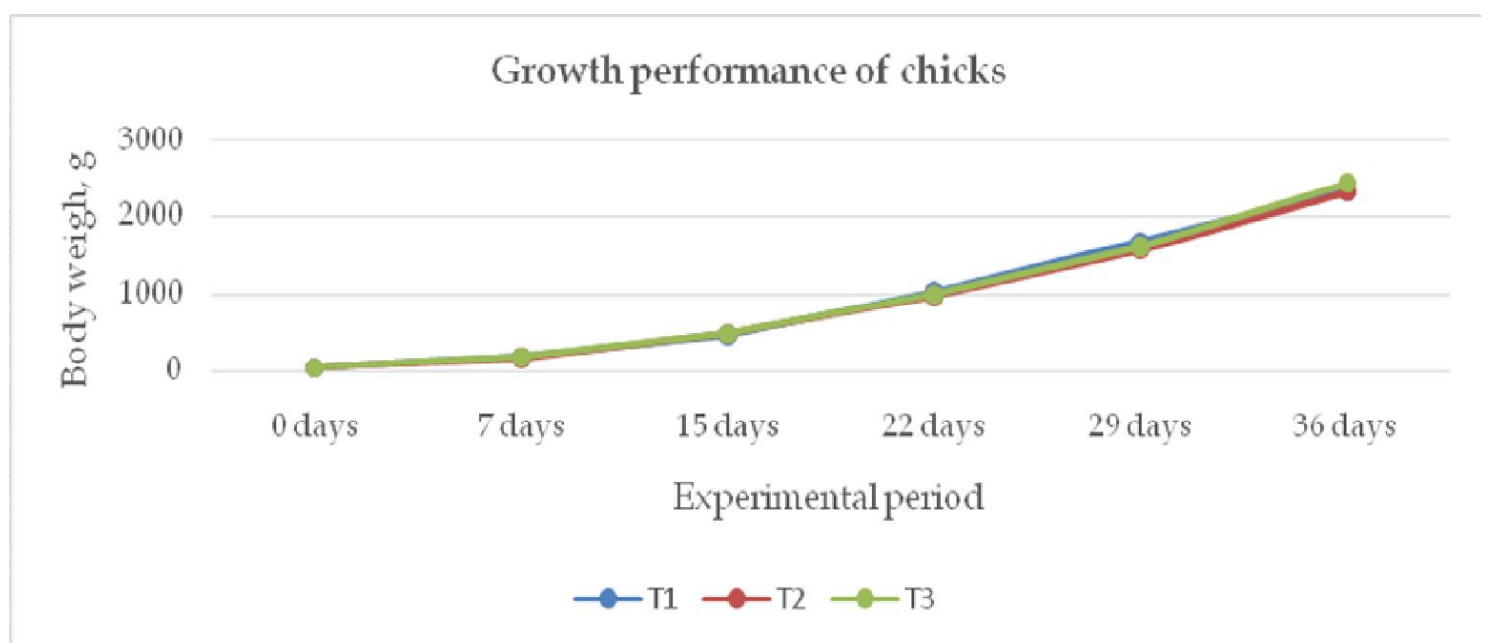

Figure 1: Trend of body weight gain fed experimental birds 
Tiwari et al. (2018) Bang. J. Anim. Sci. 47 (2):85-91

\section{Discussion}

Our experiment showed that broilers fed diets treated with various levels of LGO consumed significantly more amount of feed $3442.17 \mathrm{~g}$, $3377.33 \mathrm{~g}$ and $3354.04 \mathrm{~g}$ for $T_{3}, T_{4}$ and $T_{2}$, respectively compared to the broilers fed control diet $3330.95 \mathrm{~g}$ which was statistically nonsignificant. This positive effects of essential oil on feed consumption can be evaluated on the basis of different perspectives, firstly, the appropriateness of the extract levels for broilers and associated improvement in the feed taste, due to the essential oil as natural feed improving diet palatability, enhancing appetite of poultry, secondly the quicker passage and digestion of nutrients through the digestive effects of these natural products. These findings were in agreed with those of (Alcicek et al., 2004). These results contradictory with the finding of Abaza et al. (2008) who found that addition of black cumin essential oil in the diet reduced significantly feed consumption of broilers. Similarly, the experiment revealed that the body weight gain was also higher $2385.13 \mathrm{~g}$ in T3 where LGO was included $400 \mathrm{ml} / 100 \mathrm{~kg}$ feed compared to the control group $2279.46 \mathrm{~g}$. This result was in the line of Tekeli (2011), where he noted that chicks fed on diet with supplemented LGO recorded significantly heavy weight gain, This improves may be attributed to the increase in total feed consumption, the active compounds, antimicrobial and antioxidant activities of the LGO. These results are in agreement with Tekeli (2011) and Mukhtar (2011) where their experiment revealed significantly improve in feed conversion ratio for broilers fed diets supplemented with various levels of LGO compared with the control group.

Several studies have been reported by the different researcher on the inclusion of lemongrass in broiler diet. Khattak et al. (2013) reported that the inclusion of lemongrass in the broiler diet improves the body weight gain with positive effects on feed conversion ratio. Cabuk et al. (2006) reported that the inclusion of lemongrass @ $24 \mathrm{mg} / \mathrm{kg}$ diet significantly improves the egg production, FCR and also reduction in the percentage of cracked eggs. Ozek (2011) reported that the use of lemongrass along with organic acid supplementation in commercial layers diet reduced the heat stress and also beneficial to increase the egg weight. Mukhtar et al. (2012) reported that 50, 100 and $150 \mathrm{ml} / \mathrm{kg}$ feed supplementation of lemongrass oil in broiler diets increased feed consumption. An experiment conducted by Mmereole (2010) to evaluate the effects of dietary inclusion of lemongrass leaf meal (LGLM) on growth performances of broiler chickens and its ability to be utilized as a viable alternative to antibiotic growth promoters. The experiment involved two hundred and seventy day-old Abor-acre broiler chickens randomly separated into 3 experimental diet groups, with each being replicated 3 times. Ninety day-old birds were randomly allocated to each group and thirty birds per replicate. The diet groups were: Diet 1 (D $1=$ control = basal diet), Diet 2 (D 2 = basal diet $+1 \%$ LGLM) and Diet 3 (D $3=$ basal diet $+1 \%$ Teramycin antibiotic growth promoter). The results obtained indicated that the performances of the birds placed on control diet $D_{1}$ were significantly $(P<0.05)$ lower in all parameters than those placed on $D_{2}$ and $D_{3}$. The results further indicated that, although the final body weight of the birds on $D_{2}(1895.56 \mathrm{~g})$ was quantitatively higher than that of the birds in $D_{3}(1875.92 \mathrm{~g})$, the difference was not significant $(P>0.05)$. With respect to feed intake and feed conversion ratio, it was observed that there were no significant differences between the birds in $D_{2}$ and $D_{3}$.

Sariozkan et al. (2016) conducted to determine the effects of supplementation of lemongrass leaf meal on performance, carcass quality traits, and marketing of quail. A total of 150 , four-day-old quail were distributed into three groups with five replicates and 10 quail each. Quail were fed either basal diet (control group) or $1.5 \%$ and $3 \%$ lemongrass leaf meal supplemented to basal diets for 5 weeks period. Lemongrass supplementation ratio did not affect significantly on live weight gain $(P>0.05)$ at $1.5 \%$ level, however, $3 \%$ supplementation decreased live weight $(P<0.05)$. Feed consumption and feed conversion ratio were not affected by lemongrass supplementation.

Mukhtar et al, (2012) conducted an experiment on broiler chicks for 42 days formulating five experimental diets (A, B, C, D and E). Diet A was control, diet $B$ was supplemented with antibiotic (Neomycin $16 \mathrm{mg} / \mathrm{kg}$ ) while diets C, D and E were supplemented with (LGO) at 50,100 and $150 \mathrm{mg} / \mathrm{kg}$, respectively. Result obtained showed that addition of LGO significantly improved $(P<0.05)$ body weight gain, feed intake and feed conversion ratio of broiler chicks as compared to the control group while nonsignificant $(P>0.05)$ differences were noted among broilers fed on diets supplemented with 
LGO and antibiotic supplemented groups, respectively. Results revealed nonsignificant differences $\quad(P>0.05)$ among all treatment groups regarding carcass dressing percentages giblet, commercial cuts (breast, drumstick and thigh) and percentage of their separable tissue, meat chemical composition and subjective meat quality parameters. Economically the addition of LGO improved the performance of broiler chicks and resulted in economic benefits. Moreover, this study showed that LGO, when added as the growth promoter in broiler diets, had a similar effect like that with an antibiotic without any adverse effects. Tiwari et al. (2017) conducted an experiment on broiler chicken and reported that inclusion of LGO improved the weight gain, reduce mortality and can reduce the period of broiler harvesting.

\section{Conclusion}

This experiment revealed that the inclusion of lemon grass oil in broiler diet could be considered as an alternative to antibiotic growth promoter in broiler to enhance the production performance of broiler chicken.

\section{Acknowledgement}

Authors are grateful to the Nepal Agricultural Research Council for funding of this research work. Authors are also thankful to Md Tufel Aftar (Regional Director), Mr DilipSah (Technical Officer) and Narayan Das (Animal attendant) for their continuous coordination through the whole research work. Authors are also thankful to all scientific, technical, admin and finance staff of Animal Nutrition Division, Khumaltar, Lalitpur for their endless scientific and technical assistance.

\section{References}

Abaza IM, MA Shehata, MS Shoieb and II Hassan (2008). Evaluation of some natural feed additive in growing chicks' diets. International Journal of Poultry Science 7:872-879.

Alçiçek A, M Bozkurt and M Çabuk (2004). The effect of a mixture of herbal essential oils, an organic acid or a probiotic on broiler performance. South African Journal of Animal Science 34:217-222.

AOAC (1995).Official Methods of Analysis, $16^{\text {th }}$ edition. Association of the Official Analytical Chemists, Washington D.C.

Bampidis VA, V Christodoulou, P Florou-Paneri, E Christaki, PS Chatzopoulou, $T$ Tsiligianni and $A B$ Spais (2005). Effect of dietary dried oregano leaves on growth performance, carcase characteristics and serum cholesterol of female early maturing turkeys. British Poultry Science 46:595-601.

Cabuk M, M Bozkurt, A Alcicek, Y Akbap and K Küçükyýlmaz (2006). Effect of a herbal essential oil mixture on growth and internal organ weight of broilers from young and old breeder flocks. South African Journal of Animal Science 36:135141.

Cross DE, RM McDevitt, $\mathrm{K}$ Hillman and $\mathrm{T}$ Acamovic (2007). The effect of herbs and their associated essential oils on performance, dietary digestibility and gut micro flora in chickens from 7 to 28 days of age. British Poultry Science 8:496-506.

Goering HK and Van Soest (1970). Forage fiber analysis. Apparatus, reagents, procedures and some applications. pp. 379:20.

Khattak F, A Ronchi, P Castelli and N Sparks (2013). Effects of natural blend of essential oil on growth performance, blood biochemistry, cecal morphology, and carcass quality of broiler chickens. Poultry Science 93:132-137.

Krishi Diary (2017). Agriculture Information and Communication Center. Ministry of Agriculture Development. Singh Durbar, Kathmandu, Nepal.

Lewis WH (1986). The useful plants of west tropical Africa. Economic Botany 40: 176-178.

Mmereole FU (2010). Effects of lemon grass (Cymbopogoncitratus) leaf meal feed supplement on growth performance of broiler chicks. International Journal of Poultry Science 9:1107-1111.

MoAD (2072/73). Ministry of Agriculture Development. Statistical Information on Nepalese Agriculture. Singh Durbar, Kathmandu, Nepal

Mukhtar A, K Mohamed, O Amal and A Ahlam (2012). Effect of different levels of lemon grass oil as anatural growth promoter on the performance, carcass yields and serum chemistry of broiler chicks. Egyptian Poultry Science 33:1-7.

Mukhtar MA (2011). The effect of dietary clove oil on broiler performance. Australian Journal of Basic and Applied Sciences 5:49-51.

Omer HA, HM Elallawy, LA El-Samee and N Maghraby (2010). Productive performance of rabbits fed diets containing lemongrass or active dried yeast. American-Eurasian Journal of Agricultural and Environmental Science 7:179187.

Özek K, KT Wellmann, B Ertekin and B Tarım (2011). Effects of dietary herbal essential oil mixture and organic acid preparation on laying traits, gastrointestinal tract characteristics, blood parameters and immune response of laying hens in a hot summer season. Journal of Animal and Feed Sciences 20:575-586. 
Tiwari et al. (2018) Bang. J. Anim. Sci. 47 (2):85-91

Peter KV and KN Babu (2012). Introduction to herbs and spices: medicinal uses and sustainable production. In Handbook of Herbs and Spices (Second Edition) 2:1-16.

Sariözkan S, Y Konca, GüçlüBk, E Aktuğ, M Kaliber, Ş Özkan and ST Ay (2016). The effect of dietary supplementation of lemongrass (Cymbopogoncitratus) on performance, carcass quality, and marketing of quail (Coturnix coturnix japonica). Veterinary Medicine 98-103.

Shah G, R Shri, V Panchal, N Sharma, B Singh and AS Mann (2011). Scientific basis for the therapeutic use of Cymbopogoncitratus, stapf (Lemon grass). Journal of Advanced Pharmaceutical Technology and Research 2:3-8.

Tartrakoon W, K Wuthijaree, $\mathrm{T}$ Vearasilp and $\mathrm{U}$ terMeulen (2002). Use of lemon grass oil as feed additive in weanling pig diets. In Conference on International Agricultural Research for Development. DeutscherTropentag, Witzenhausen, pp. 9-11.
Tekeli A, HR Kutlu and L Celik (2011). Effects of officinale and propolis extracts on the performance, carcass and some blood parameters of broiler chicks. Current Research in Poultry Science 1:12-23.

Thayalini K, S Shanmugavelu, PM Saminathan, MS SitiMasidayu, Y Noridayusni, H Zainmuddin, C NurulAkmai and $\mathrm{H}$ Wong (2011). Effects of cymbopogoncitratus leaf and zingiberofficinale rhizome supplementation on growth performance, ileal morphology and lactic acid concentration in broilers. Malaysian Journal of Animal Science 14:43-49.

Tiwari MR, B Sah, AK Jha and MP Sah (2017). Lemon grass oil feeding in relation to growth and carcass characteristics of broiler chicken. Nepalese Journal of Agricultural Sciences 15: 67-74. 